\title{
RADIATION AND CLOUD OBSERVATIONS ON A HIGH ARCTIC PLATEAU ICE CAP
}

\author{
By M.C. SERREZE \\ (CIRES, University of Colorado, Boulder, Colorado 80309, U.S.A.) \\ and R.S. BRADLEY \\ (Department of Geology and Geography, University of Massachusetts, Amherst, \\ Massachusetts 01003, U.S.A.)
}

\begin{abstract}
Hourly measurements of incoming short-wave and long-wave radiation, surface albedo, and net radiation were made on and around a plateau ice cap on north-eastern Ellesmere Island during the summers of 1982 and 1983. These data were stratified by cloud type and amount. All cloud types increased incoming long-wave radiation, especially low dense clouds, fog, and clouds associated with snowfall. Relative transmission of incoming short-wave radiation, expressed as a percentage of clear-sky radiation receipts, was high for all cloud types compared to clouds at lower latitudes. With high surface albedo $(30.75)$, net radiation was strongly and positively correlated with net long-wave radiation but showed little relationship to net short-wave radiation. By contrast, with low surface albedo $(\$ 0.20)$ net radiation was negatively correlated with net long-wave radiation but positively correlated with net shortwave radiation. Under high-albedo conditions, an increase in cloudiness led to higher values of net radiation but under low-albedo conditions net radiation decreased as cloud cover increased. Survival of a snow cover would seem to be favoured if the seasonal decline in albedo is accompanied by a corresponding increase in cloudiness.
\end{abstract}

\section{INTRODUCTION}

Meteorological observations were carried out in the summers of 1982 and 1983 on and around "St. Patrick Bay Ice Cap", northern Ellesmere Island, N.W.T., Canada (lat. $81^{\circ} 57^{\prime} \mathrm{N}$., long. $64^{\circ} 10^{\prime} \mathrm{W}$.). The ice cap is situated on the Hazen Plateau at an elevation of $\sim 850 \mathrm{~m}$ above sea-level (Fig. 1). Because the surrounding topography is so flat, the ice cap is completely unshaded so the effects of slope and aspect on topoclimate are minimized.

Observations were initiated to determine a possible mechanism by which the ice cap, through modification of the local climate, assists in its own preservation (Bradley and Serreze, 1987). One such potential mechanism involves the noted high sensitivity of net radiation over Arctic snow surfaces to variations in cloudiness and surface albedo (e.g. Jacobs and others, 1973; Ambach, 1974; Crane, 1979). These studies concluded that, for a high-albedo snow surface, net radiation under clear skies is significantly lower than the corresponding value under cloudy skies with identical surface conditions.

From the results of these and other studies, we hypothesized that seasonal variations in spring/summer cloudiness may interact with variable surface albedo so as to affect positively the mass balance of the ice cap. To assess this possibility, hourly measurements of short-wave and long-wave radiation, surface albedo, and net radiation were recorded and were stratified by cloud type and amount. Instrumentation used is shown in Table I.

\section{OVERVIEW OF CONDITIONS IN 1982 AND 1983}

Daily totals of incoming short-wave $\left(Q_{\mathrm{i}}\right)$ and long-wave radiation $\left(I_{\mathrm{i}}\right)$ recorded at station Yankee are shown in

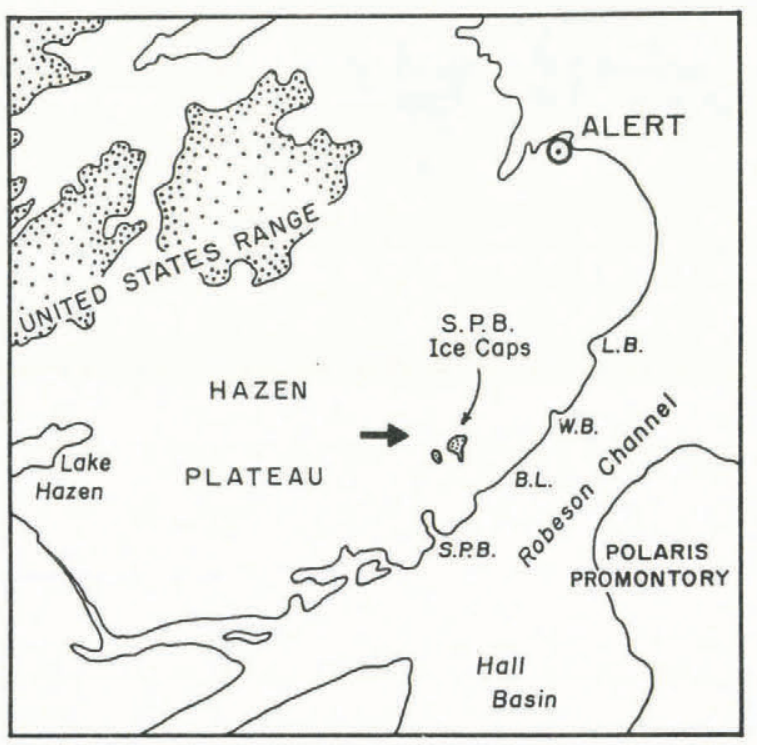

Fig. 1. Location map; S.P.B., St. Patrick Bay; B.L., Beaufort Lakes; W.B., Wrangel Bay; L.B., Lincoln Bay.

TABLE I. RADIATION INSTRUMENTS USED IN STUDY

Incoming and reflected short-wave radiation $\left(Q_{i}\right.$ and $\left.Q_{o}\right)$

Eppley "black and white" pyranometers, Model 8-48

Incoming long-wave radiation $\left(I_{i}\right)$

Eppley precision infra-red radiometer (pyrgeometer)

Net radiation ( $R$ )

"Fritschen type" net radiometers (Micromet Instruments) 
Figures 2 and 3 . At this site, $Q_{\mathrm{i}}, I_{\mathrm{i}}, Q_{\mathrm{\rho}}$ (outgoing shortwave radiation), and $R$ (net radiation) were measured direcily. This station was located approximately $1 \mathrm{~km}$ from the southern edge of the ice cap over a till surface that was snow-covered early in the measurement period and became fully exposed later in the season. Surface albedo varied between 0.90 and 0.16 during the measurement period (Julian Days (JD) 160-208). Large day-to-day fluctuations in $Q_{\mathrm{i}}$ are associated with synoptic-scale events, with peaks associated with clear-sky conditions. Near the solstice (JD 172), with a nearly complete (approximately $95 \%)$ snow cover, short-wave $(0.28-2.80 \mu \mathrm{m})$ atmospheric transmission in clear skies at local noon was 0.77 in 1982 and 0.74 in 1983. These values compare with a summer-time value of 0.81 recorded by Holmgren (1971) on the Devon Island Ice Cap in late June. This higher value primarily reflects the higher elevation $(1320 \mathrm{~m})$ of the Devon Island station as compared to "St. Patrick Bay Ice Cap", although differences in atmospheric turbidity, humidity, and instrument types may also be a factor.

Day-to-day fluctuations of $I_{\mathrm{i}}$ are much smaller compared to $Q_{\mathrm{i}}$ (Figs 2 and 3 ), and there is a close inverse relationship between the two variables due to the influence of cloudiness. Under clear skies, $Q_{\mathrm{i}}$ is high with fairly low values of $I_{\mathrm{i}}$. Conversely, under cloudy skies, $Q_{\mathrm{i}}$ is lower

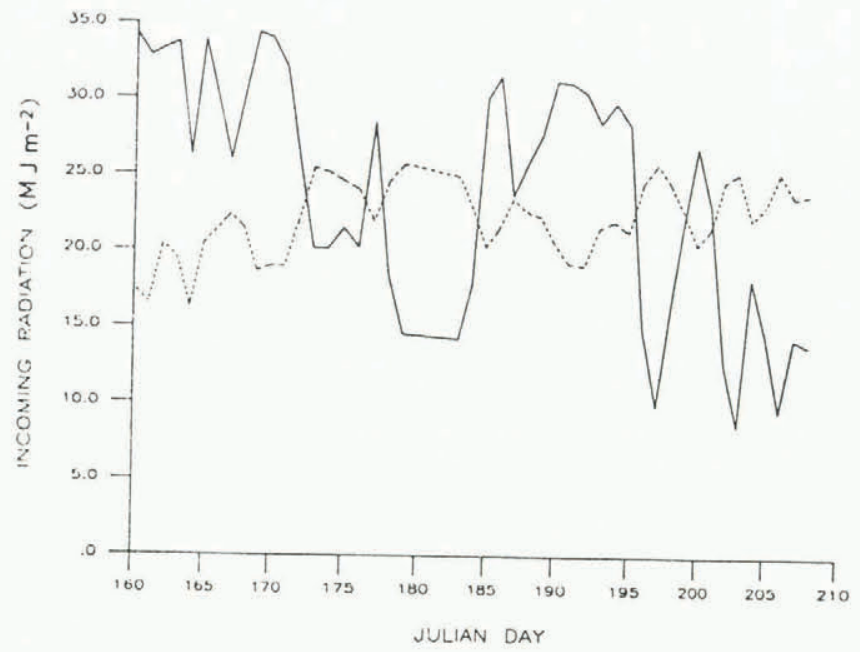

Fig. 2. Daily receipts of incoming short-wave radiation $\left(Q_{i}\right)$ (solid line) and long-wave radiation $\left(I_{i}\right)$ (dashed line) in 1982 at station Yankee.

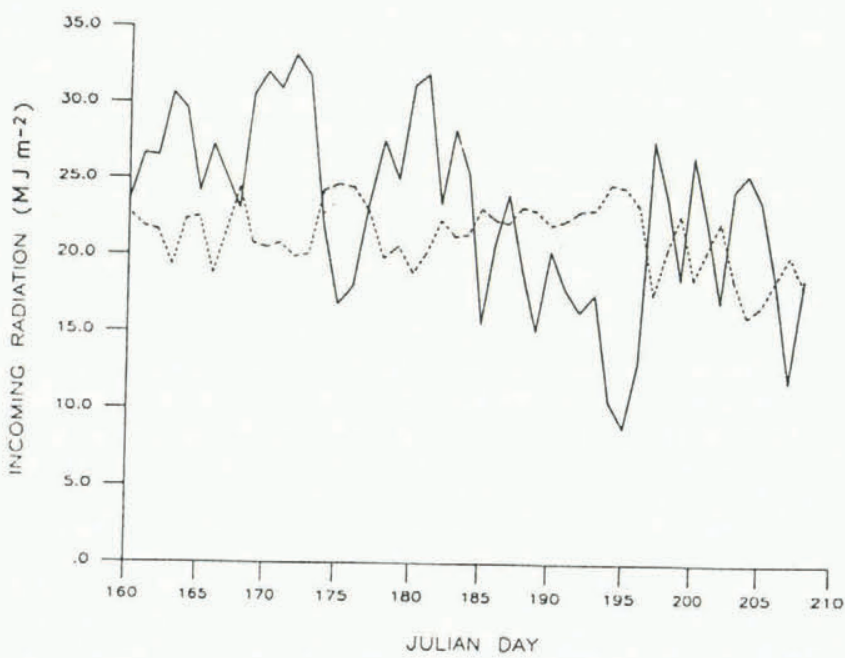

Fig. 3. Daily receipts of incoming short-wave radiation $\left(Q_{i}\right)$ (solid line) and long-wave radiation $\left(I_{i}\right)$ (dashed line) in 1983 at station Yankee. but clouds increase counter radiation. Under dense overcast, $I_{\mathrm{i}}$ may exceed $Q_{\mathrm{i}}$ (e.g. JD $188-196$ in 1983; Fig. 3). The result of this balancing relationship between $Q_{j}$ and $I_{\mathrm{i}}$ is that the daily variability of total incoming radiation is rather moderate and less than expected on the basis of $Q$ alone.

Mean hourly totals of $Q_{\mathrm{i}}$ and $I_{\mathrm{i}}$ are shown in Figure 4. $Q_{\mathrm{i}}$ exhibits a clear diurnal pattern, with slightly lower values in 1983 when cloudiness was generally greater

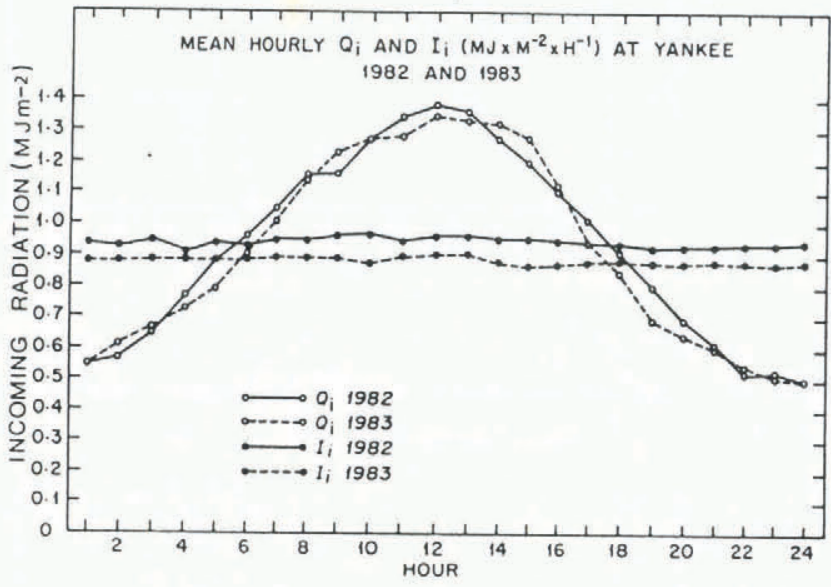

Fig. 4. Mean hourly $Q_{i}$ and $I_{i}$ at station Yankee in 1982 and 1983 (for Julian Days 170-207 in both years).

(averaging $7 / 10$ in 1983 and $6 / 10$ in 1982). In both years, $I_{\mathrm{i}}$ shows little diurnal variation, reflecting a fairly even cloud cover, fairly windy conditions, and a $24 \mathrm{~h}$ daylight period, resulting in a small diurnal temperature range. Despite the slightly greater cloudiness in 1983, values of $I_{\mathrm{i}}$ are lower than in 1982 due to the significantly colder conditions in 1983.

\section{THE ROLE OF CLOUD COVER ON $Q_{\mathrm{i}}$ AND $I_{\mathrm{i}}$}

Two seasons of hourly surface observations of cloudiness allow an analysis of the role of cloudiness on $Q_{i}$ and $I_{\mathrm{i}}$. Hourly totals of $Q_{\mathrm{i}}$ measured under clear skies and different cloud types are plotted against solar angle (as measured from a horizontal plane) in Figure 5. Data from station Yankee for both years are used. In order to have enough cases for analysis, clear skies are defined as $\$ 3 / 10$ cloudiness, and for each cloud type cloudiness was $37 / 10$. A linear regression analysis has been adopted, and seems to work well for the range of solar angles in which observations were made $\left(-12-30^{\circ}\right)$. Correlation coefficients between solar angle and $Q_{\mathrm{i}}$ are uniformly high and significant $(p=0.001)$. Extrapolating beyond this range is obviously problematical (note negative $y$-intercepts). Although various non-linear functions were fitted to the data, they resulted in no significant improvement in the correlations. Some scatter is inevitably introduced due to a comparison of hourly radiation totals with instantaneous (hourly) cloud observations and, although measurements took place over two seasons as surface albedo changed, some meaningful information can be extracted.

To enable clear-sky radiation receipts to be compared with those under different cloud types, the regression line for clear-sky conditions (top left section of Figure 5) is shown as a solid dark line in the other diagrams. Table II compares the relative transmission of $Q_{\mathrm{i}}$ as a percentage of clear-sky surface radiation for different cloud types for solar angles of $12^{\circ}$ and $30^{\circ}$. The difference in relative transmission between these two solar angles is also shown (cf. Angström and Tryselius, 1934; Haurwitz, 1946, 1948; Liljequist, 1956; Vowinkel and Orvig, 1962; Holmgren, 1971). As expected, for the thinner, higher cloud types 

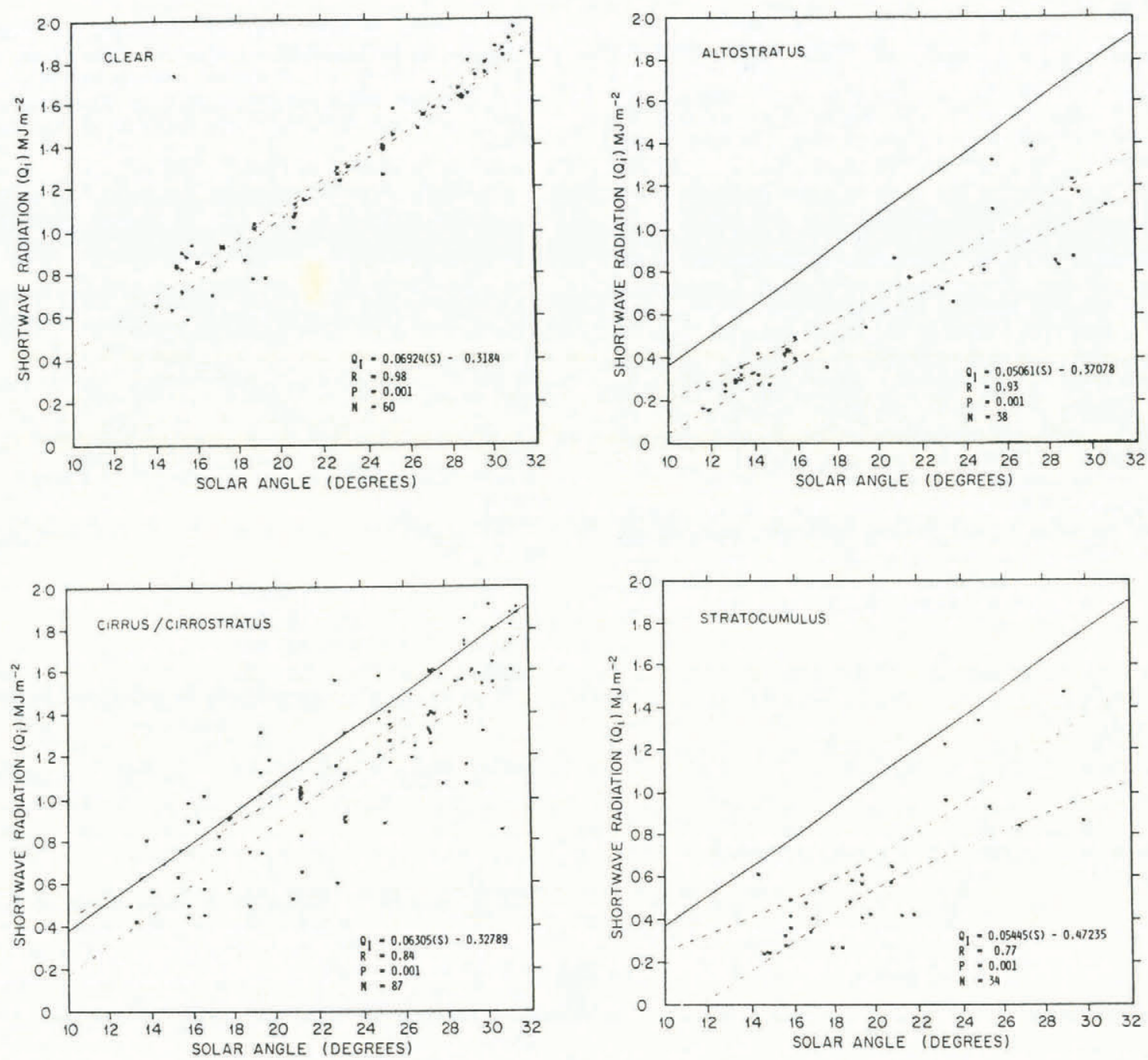

TABLE II. RELATIVE TRANSMISSION OF $Q_{\mathrm{i}}$ FOR SOLAR ANGLES $12^{\circ}$ AND $30^{\circ}$ UNDER DIFFERENT CLOUD TYPES $(\%)$
(a) $12^{\circ}$
(b) $30^{\circ}$
(c) $b-a$

Cirrus/cirrostratus

Altocumulus

84
58
50
46
46
35
33

89
78
54
67
65
66
59

5
20
4
21
19
31
26

\section{Fog}

Altostratus

Stratocumulus

Snow

50

68

(cirrus/cirrostratus), relative transmission is high (84-89\%) while for the lower thicker cloud types, and snowfall, relative transmission is much lower (as low as 33\%).

In comparison with clouds in temperate regions, Arctic clouds are noted for their higher relative transmission. This is due to Arctic clouds being thinner than temperate clouds, due to limited convection and lower absolute humidities. Ángström and Tryselius (1934) arrived at an annual mean of $23 \%$ relative transmission under dense overcast conditions in temperate regions. By contrast, in Antarctica, Liljequist (1956) arrived at a mean of $60 \%$, while Holmgren (1971), on the Devon Island Ice Cap, noted even higher values of up to $70 \%$. Both of the latter were summer-time values.

Our measurements, over a range of solar angles from $12^{\circ}$ to $30^{\circ}$ give a mean relative transmission for all cloud types of $50-68 \%$ (Table II).

Measurements of $I_{\mathrm{i}}$ showed virtually no dependence on solar angle and, on the average, no diurnal change (Fig. 4). The reasons for this are noted earlier. In comparison with clear-sky conditions, all cloud types (except cirrus/cirrostratus at low solar angles) result in an increase in $I_{\mathrm{i}}$. The effect is most pronounced for denser cloud types, snow, and fog. This is summarized in Table III which ranks $I_{\mathrm{i}}$ according to a regression-derived value for solar angle of $20^{\circ}$. It is clear that cloud types associated with the highest receipts of $I_{\mathrm{i}}$ (stratocumulus, stratus, snow, and fog) are also associated with low relative transmission of $Q_{\mathrm{i}}$ (Table II).

\section{THE ROLE OF ALBEDO AND CLOUD COVER ON NET RADIATION}

Interactions between cloudiness and the surface play a major role in the radiation balance of a region. Surface albedo is an important component in these interactions. Here, we consider the role of albedo and cloudiness on net radiation $(R)$ at the surface.

Tables IV and $\mathrm{V}$ present correlation matrices between $R, Q_{\mathrm{i}}, I_{\mathrm{i}}$, and the net long-wave $\left(I_{\mathrm{n}}=I_{\mathrm{i}}+I_{0}\right)$ and net short-wave $\left(Q_{n}=Q_{i}+Q_{0}\right)$ hourly radiation totals for conditions of high $(\$ 0.75)$ and low $(\leqslant 0.20)$ surface albedo. Outgoing long-wave radiation (emitted and reflected) was calculated as a residual of the radiation-balance equation $\left(I_{0}=R-Q_{\mathrm{i}}-Q_{0}-I_{\mathrm{i}}\right)$, where radiation terms are considered positive when directed towards the surface. Used in this analysis are 1982 data from station Yankee, which 

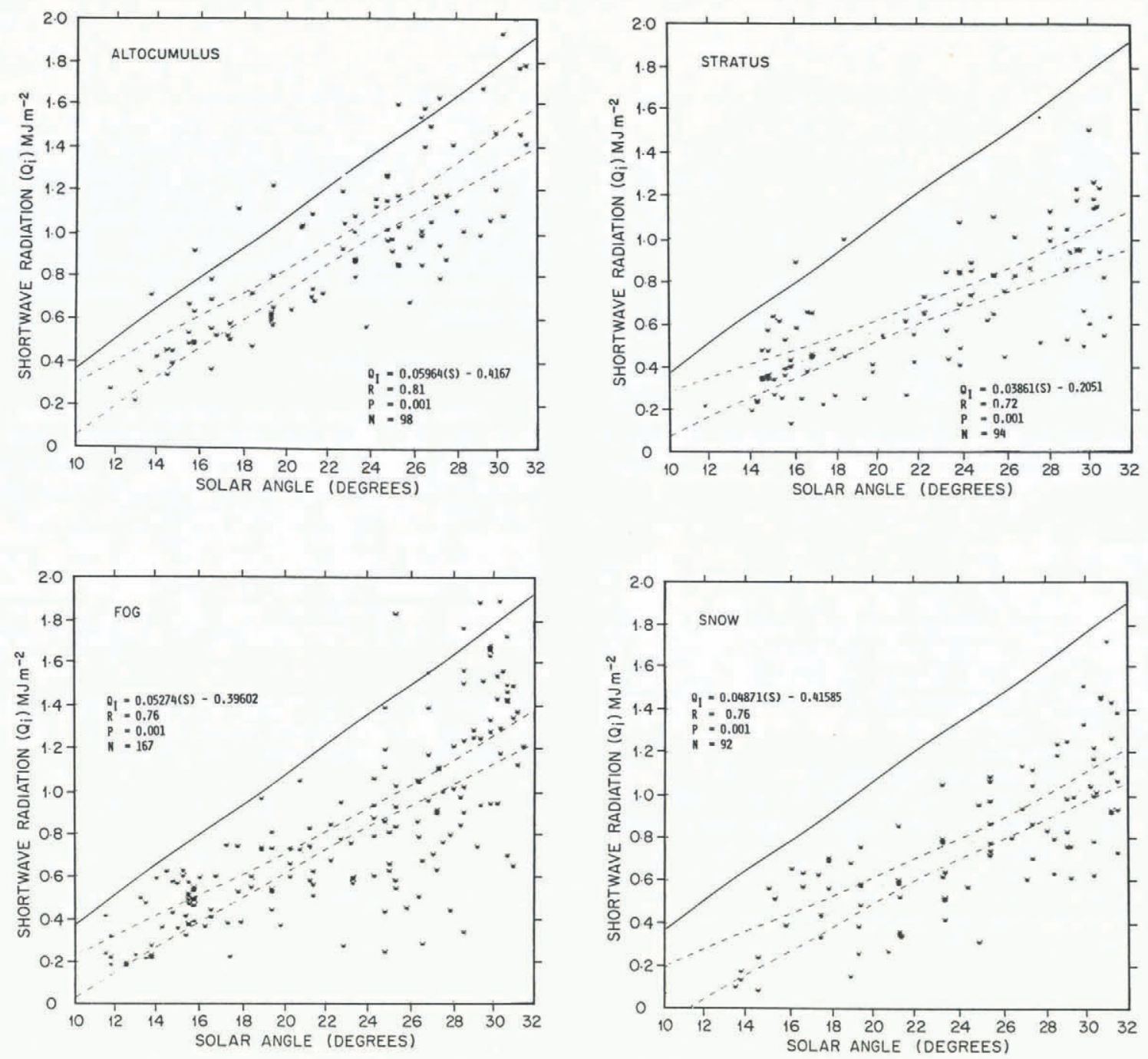

Fig. 5. Mean hourly totals of $Q_{i}\left(M J m^{-2} h^{-1}\right)$ vs solar angle for clear skies ( $\leqslant 3 / 10$ cloud cover) and different cloud types ( $\geqslant 7 / 10$ cloud cover). The regression line for each sky condition is enclosed by $95 \%$ confidence intervals. The regression equation, correlation coefficient $(R)$, significance $(p)$, and number of cases ( $N$ ) for clear skies and the different cloud types are also shown. In the regression equations, solar angle is abbreviated as $S$. The solid line is the regression line for clear skies.

TABLE III. RANKING OF $I_{\mathrm{i}}$ FOR DIFFERENT SKY CONDITIONS WITH SOLAR ANGLE OF $20^{\circ}\left(\mathrm{MJ} \mathrm{m}^{-2} \mathrm{~h}^{-1}\right)$

$\begin{array}{lrr}\text { Cirrus/cirrostratus } & 0.773 & 96 \% \\ \text { Clear skies } & 0.802 & 100 \% \\ \text { Altocumulus } & 0.862 & 108 \% \\ \text { Altostratus } & 0.921 & 115 \% \\ \text { Stratus } & 0.939 & 117 \% \\ \text { Fog } & 0.983 & 123 \% \\ \text { Stratocumulus } & 0.994 & 124 \% \\ \text { Snow } & 1.021 & 127 \%\end{array}$

${ }^{*}$ Relative to clear-sky conditions at $20^{\circ}$ solar angle.

operated over a low-albedo till surface in the latter part of the measurement season (Bradley and Serreze, 1987) and 1983 data from station Zebra, which operated in the center of the ice cap over a uniform high-albedo snow cover. Only $Q_{0}$ and $R$ were measured at station Zebra. To close the radiation balance for this site, values for $I_{\mathrm{i}}$ and $Q_{\mathrm{j}}$ were taken from station Yankee. Due to the proximity of the two sites $(\sim 2 \mathrm{~km})$ and the fact that both sites were underlain by a snow cover in 1983, we assume that $I_{\mathrm{i}}$ and $Q_{\mathrm{i}}$ are identical at both sites. Using these two data sets, the effects of cloudiness on $R$ under conditions of high and low albedo were investigated. It should be noted that the two data sets are from different years and $I_{\mathrm{i}}$ was significantly lower in 1983 .

TABLE IV. CORRELATION MATRIX OF $R, Q_{\mathrm{i}}, I_{\mathrm{i}}, I_{\mathrm{n}}$,
AND $Q_{\mathrm{n}}$ FOR HIGH-ALBEDO CONDITIONS $(\geqslant 75 \%)^{*}$ AND $Q_{\mathrm{n}}$ FOR HIGH-ALBEDO CONDITIONS $(\geqslant 75 \%)^{*}$

\begin{tabular}{|c|c|c|c|c|}
\hline$I_{\mathrm{i}}$ & $\begin{array}{c}-0.54 \\
(741)\end{array}$ & & & \\
\hline$I_{\mathrm{n}}$ & $\begin{array}{c}-0.59 \\
(741)\end{array}$ & $\begin{array}{l}0.57 \\
(741)\end{array}$ & & \\
\hline$Q_{\mathrm{n}}$ & $\begin{array}{c}0.90 \\
(742)\end{array}$ & $\begin{array}{c}-0.51 \\
(741)\end{array}$ & $\begin{array}{c}-0.66 \\
(741)\end{array}$ & \\
\hline$R$ & $\begin{array}{c}0.08 \\
(742)\end{array}$ & $\begin{array}{l}0.27 \\
(741)\end{array}$ & $\begin{array}{l}0.69 \\
(741)\end{array}$ & $\begin{array}{l}0.08 \\
(742)\end{array}$ \\
\hline
\end{tabular}

*The number of cases is shown in parentheses. All correlations are highly significant $(p=0.001)$ except for that of $R, Q_{\mathrm{i}}$, and $Q_{\mathrm{n}}$ 
TABLE V. CORRELATION MATRIX OF $R, Q_{\mathrm{i}}, I_{\mathrm{i}}, I_{\mathrm{n}}$, AND $Q_{\mathrm{n}}$ FOR LOW-ALBEDO CONDITIONS ( $\left.\leqslant 20 \%\right)^{*}$

$\begin{array}{lcccc} & Q_{\mathrm{i}} & I_{\mathrm{i}} & I_{\mathrm{n}} & Q_{\mathrm{n}} \\ I_{\mathrm{i}} & -0.55 & & & \\ & (544) & & & \\ I_{\mathrm{n}} & -0.86 & 0.72 & & \\ & (544) & (544) & & \\ Q_{\mathrm{n}} & 0.99 & -0.54 & -0.86 & \\ & (544) & (544) & (544) & \\ & & & & \\ R & 0.96 & -0.38 & -0.69 & 0.96 \\ & (544) & (544) & (544) & (544)\end{array}$

*The number of cases is shown in parentheses. All correlations are highly significant $(p=0.001)$.

\section{HIGH ALBEDO ( $(00.75)$}

Under conditions of high albedo, $R$ is best correlated (positive) with $I_{\mathrm{n}}$, and poorly correlated with $Q_{\mathrm{i}}, Q_{\mathrm{n}}$, and $I_{\mathrm{i}}$ (Table IV). This is clearly seen in Figure 6 , where $R$ is plotted against $I_{\mathrm{n}}$ and $Q_{\mathrm{n}}$. Similar relationships were found by Hoinkes (1970), Holmgren (1971), Ambach (1974), and Kuhn and others (1975). They noted that $I_{\mathrm{n}}$ is very dependent on cloudiness.

Ambach (1974) demonstrated that, under 10/10 cloudiness, $Q_{\mathrm{i}}$ and $Q_{0}$ are reduced by cloud albedo and absorption. $Q_{n}$ is therefore also reduced but must remain positive. $I_{\mathrm{i}}$ increases with extensive cloudiness, due to enhanced counter radiation (cf. Table III). $I_{0}$ depends on the surface temperature and emissivity, and will only be marginally affected by an increase in cloudiness. Under clear skies $(0 / 10), I_{\mathrm{n}}$ is strongly negative, but under over-

cast conditions it can approach, or even exceed, zero (Bolsenga, 1977). These relationships are supported in Table IV, where $I_{\mathrm{i}}$ and $I_{\mathrm{n}}$ (hence cloudiness) are both shown to be negatively correlated with $Q_{\mathrm{i}}$.

Evidently, with extensive cloudiness, the increase in $I_{\mathrm{n}}$ more than makes up for the decrease in $Q_{n}$, resulting in an increase in $R$. This effect is clearly illustrated in Table VI, in which hourly totals of $Q_{\mathrm{n}}$ and $I_{\mathrm{n}}$ from the present study are stratified according to three conditions of cloudiness (in tenths, $0-2,3-6,7-10$, all cloud types combined, and the difference between the first and last groups). The change in $R$ from condition (a) to (c) is statistically significant $(p=0.01)$.

\section{LOW ALBEDO (\$0.2)}

With conditions of low albedo, $R$ is strongly correlated with $Q_{\mathrm{i}}, Q_{\mathrm{n}}$ (positive), and $I_{\mathrm{n}}$ (negative), and is poorly correlated with $I_{\mathrm{i}}$ (Table V). This is almost a complete reversal from the high-albedo situation. These results agree well with those of Wilson (1972), who found an almost perfect linear relationship between $Q_{\mathrm{i}}$ (and hence $Q_{\mathrm{n}}$ ) and $R$ when the albedo was low. In Figure 7, as before, $R$ is plotted against $Q_{\mathrm{n}}$ and $I_{\mathrm{n}}$. In contrast to the previous situation, variations in both $Q_{\mathrm{n}}$ and $I_{\mathrm{n}}$ exert a strong influence on $R$. The influence of cloudiness on $Q_{\mathrm{n}}$ and $I_{\mathrm{n}}$

TABLE VI. $Q_{\mathrm{n}}, I_{\mathrm{n}}$, AND $R$ STRATIFIED ACCORDING TO DIFFERENT CONDITIONS OF CLOUD COVER WITH SURFACE ALBEDO $\geqslant 75 \%\left(\mathrm{MJ} \mathrm{m}^{-2} \mathrm{~h}^{-1}\right)$

(a) $0-2$

$Q_{\mathrm{n}}$

$I_{\mathbf{n}}$

$R$ (b) 3-6

0.241

$-0.202$

0.039 (c) $7-10$

0.103

0.009

0.112 $(c-a)$

$-0.144$

0.216

0.072
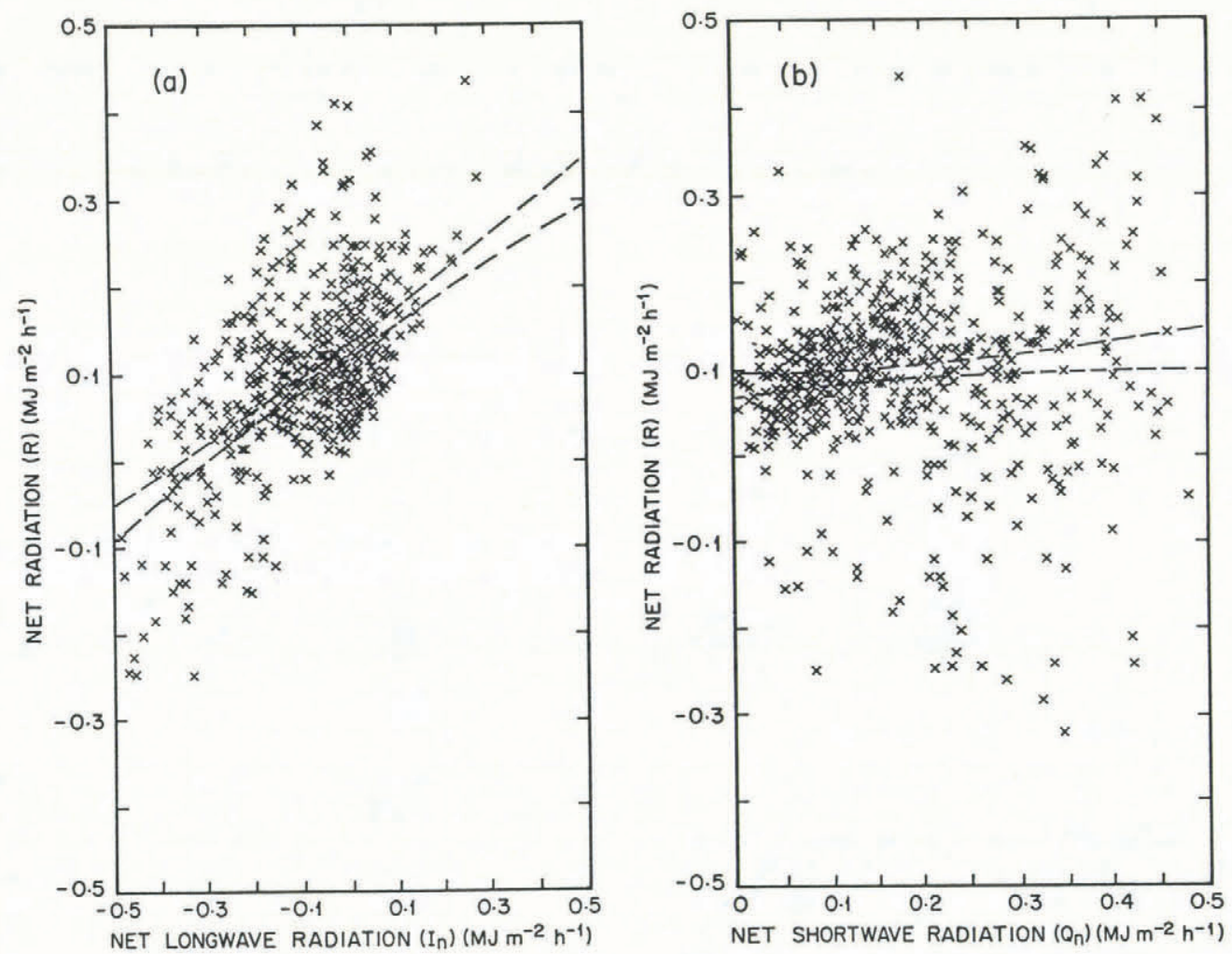

Fig. 6. Hourly totals of net radiation $(R)$ in relation to hourly totals of net long-wave radiation $\left(I_{n}\right)$ (left) and net short-wave radiation $\left(Q_{n}\right)$ for high-albedo conditions $(\geqslant 0.75)$. The dashed lines in each plot are the $95 \%$ confidence intervals on a linear regression through the data. Note differences in scale of abscissa and in scales of ordinate compared to Figure 7. 

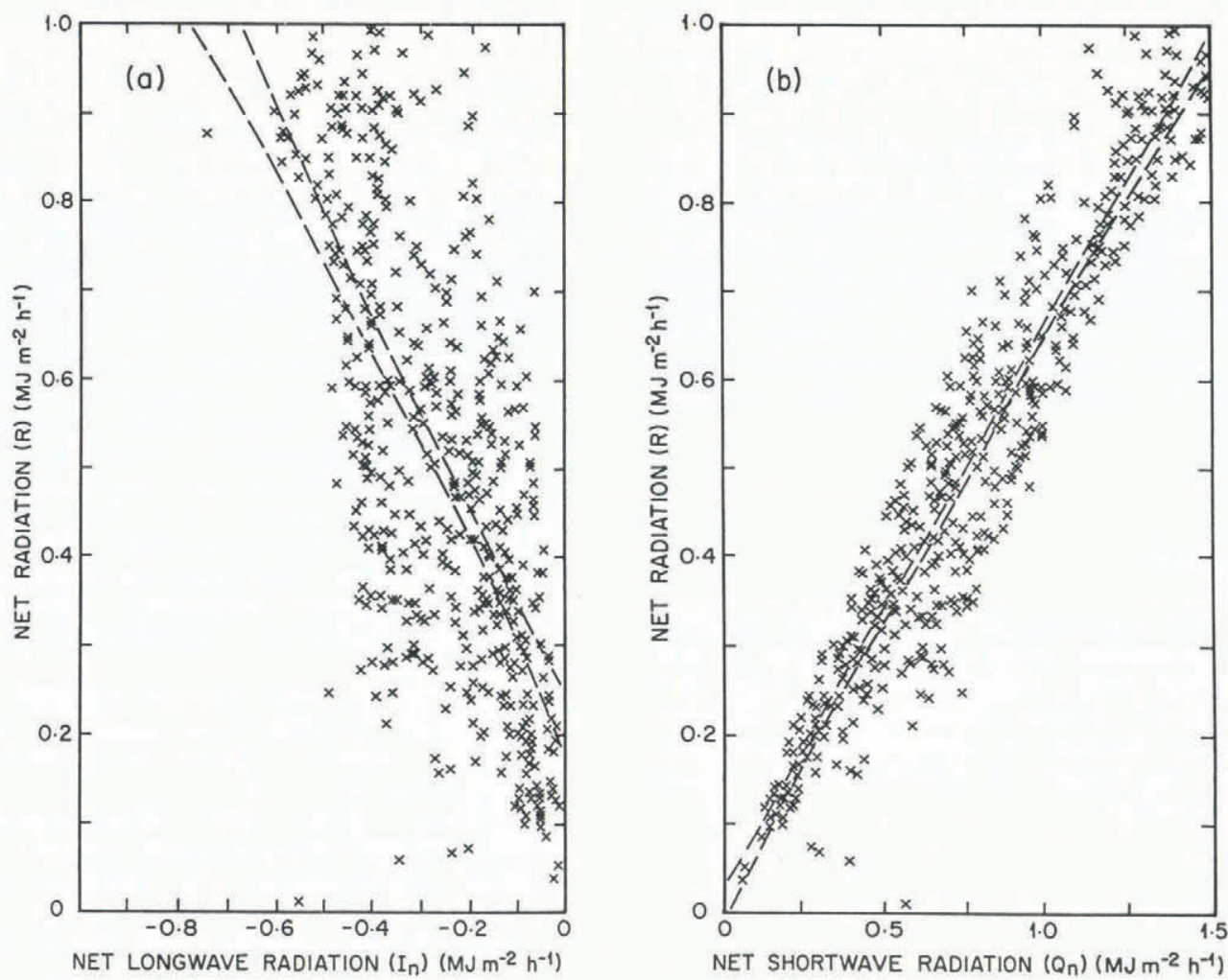

Fig. 7. Hourly totals of net radiation $(R)$ in relation to hourly totals of net long-wave radiation $\left(I_{n}\right)$ (left) and net short-wave radiation $\left(Q_{n}\right)$ (right) for low-albedo conditions $(\leqslant 0.20)$. The dashed lines on each plot are the 95\% confidence intervals on a linear regression through the data. Note differences in scales of abscissa and in scales of ordinate compared to Figure 6.

is similar to that shown in Table VI, but in this case the reduction in $Q_{\mathrm{n}}$ with increasing cloudiness more than makes up for the increase in $I_{\mathrm{n}}$. This results in a decrease of $R$. These relationships are made clear in Table VII. The change in $R$ from condition (a) to condition (c) is statistically significant $(p=0.01)$.

TABLE VII. $Q_{\mathrm{n}}, I_{\mathrm{n}}$, AND $R$ STRATIFIED ACCORDING TO DIFFERENT CONDITIONS OF CLOUD COVER WITH SURFACE ALBEDO $\leqslant 20 \%\left(\mathrm{MJ} \mathrm{m}^{-2} \mathrm{~h}^{-1}\right)$ (a) $0-2$

(b) 3-6

(c) $7-10$

$(c-a)$

$Q_{\mathrm{n}}$

0.736

0.678

$I_{\mathrm{n}}$

$R$

$-0.379$

$-0.354$

$-0.162$

0.357

0.324

0.295

$-0.062$

\section{DISCUSSION}

It is evident that the relationships between cloud cover and surface albedo exert a major control on $R$, and hence should have an influence on the mass balance of the ice cap. The relationships discussed here find support in numerous other studies. For example, Holmgren (1971), in a synoptic energy-balance study on the Devon Island Ice Cap (N.W.T., Canada), noted that the lowest values of $R$ were obtained when the surface was frozen and had a high albedo. With the same surface characteristics but with an overcast sky, $R$ rose dramatically. With a melting surface (lower albedo) and clear skies, again with light winds, $R$ attained much higher values. Similar relationships were found by Alt (1978) on the Meighen Ice Cap (N.W.T., Canada).

Table VI shows that with a high surface albedo, $R$ nearly triples from low to high cloud-cover conditions (a to c). Conversely, with low albedo (Table VII), the corresponding decrease in $R$ is much smaller in proportion but similar in absolute terms $\left(-0.062\right.$ vs $\left.0.072 \mathrm{MJ} \mathrm{m}^{-2} \mathrm{~h}^{-1}\right)$. In terms of total energy, the effect seems rather small but, since the Arctic melt season is quite short, any change in the timing and extent of melt can have a large impact on regional energy budgets (Marshunova and Chernogovskii, 1968). The relevance of our small-scale study to larger areas is suggested by studies of cloudiness and snow melt in the Arctic Basin (Robinson and others, 1985, 1986; Scharfen and others, 1987) which demonstrated links between the timing of late spring and early summer cloudiness and the progression of melting and surface-albedo change.

Little attention has been paid to the possible influences of the relationships between cloudiness, surface albedo, and net radiation on the survival of a snow cover. From the present study, it seems that clear spring-time conditions when the surface albedo is high, combined with increased cloudiness as melt commences and the surface albedo drops, could favour the survival of a snow cover. However, precisely where and when this effect would have importance is less apparent. Obviously, at some critical solar flux, the value of $R$ (and hence the amount of melt) would be enhanced by clear skies and reduced during periods of greater cloudiness, regardless of the albedo of the snow surface, so the relationship discussed here would no longer hold. Most studies of mid-latitude glaciers show this to be true (Müller, 1984). Hence, the effects discussed in this paper are probably restricted to high-latitude polar regions where radiative fluxes are rather small, the percentage change in the radiation budget being rather sensitive to the effects of cloudiness. The effect would probably also be most apparent over large, homogeneous snow surfaces where regional radiation budgets are rather uniform. Other effects which are likely manifested in our results, but have not been considered individually, may also have some importance. These include multiple reflection effects between clouds and the surface (e.g. Schneider and Dickinson, 1976; Weller and others, 1981) changes in surface albedo due to preferential 
absorption by clouds of near-infra-red radiation (Grenfell and Maykut, 1977) and albedo changes related to solar angle and specular reflection from snow surfaces (Wiscombe and Warren, 1980).

Because of the many uncertainties, the critical value of surface albedo at which an increase in cloudiness would benefit a snow cover is unknown. A minimum albedo of 0.75 , suggested by Ambach (1974), would require a change in cloud conditions while the snow cover was still fairly fresh, which would generally be the case in early to midspring. However, the critical value is probably quite variable, with the height and radiative temperature of cloud types of fundamental importance. Further study of this matter is warranted.

\section{ACKNOWLEDGEMENTS}

This research was supported by a grant from the U.S. National Science Foundation (grant ATM80-17745) to the University of Massachusetts. Logistical support from the Polar Continental Shelf Project (Department of Energy, Mines and Resources, Ottawa) is gratefully acknowledged. We thank C. Allen, M. Palecki, M. Retelle, and R. Friend for assistance in the field.

\section{REFERENCES}

Alt, B.T. 1978. Synoptic climate controls of mass-balance variations on Devon Island ice cap. Arctic and Alpine Research, Vol. 10, No. 1, p. 61-80.

Ambach, W. 1974. The influence of cloudiness on the net radiation balance of a snow surface with high albedo. Journal of Glaciology, Vol. 13, No. 67, p. 73-84.

Ångström, A., and Tryselius, O. 1934. Total radiation from sun and sky at Abisko. Geografiska Annaler, Àrg. 16 , Ht. 1, p. 53-69.

Bolsenga, S.J. 1977. Radiation balance over a continuous snow surface. Washington, DC, U.S. Department of Commerce. (NOAA, Great Lakes Environmental Research Laboratories. Contribution 108.)

Bradley, R.S., and Serreze, M. 1987. Topoclimatic studies of a High Arctic plateau ice cap. Journal of Glaciology, Vol. 33 , No. 114 , p. 149-58.

Crane, R.G. 1979. Synoptic controls on the energy budget regime of an ablating fast ice surface. Archiv für Meteorologie, Geophysik und Bioklimatologie, Ser. A, Bd. 28, p. 53-70.

Grenfell, T.C., and Maykut, G.A. 1977. The optical properties of ice and snow in the Arctic Basin. Journal of Glaciology, Vol. 18, No. 80, p. 445-63.

Haurwitz, B. 1946. Insolation in relation to cloud type. Journal of Meteorology, Vol. 3, p. 123-24.

Haurwitz, B. 1948. Insolation in relation to cloud type. Journal of Meteorology, Vol. 5, p. 110-13.

Hoinkes, H. 1970. Radiation budget at Little America V. 1957. [Union Géodésique et Géophysique Internationale. Association Internationale d'Hydrologie Scientifique.] [International Council of Scientific Unions. Scientific Committee on Antarctic Research. International Association of Scientific Hydrology. Commission of Snow and Ice.] International Symposium on Antarctic Glaciological Exploration (ISAGE), Hanover, New Hampshire, U.S.A., 3-7 September 1968, p. 263-84. [(Publication No. 86 [de l'Assocation Internationale d'Hydrologie Scientifique].)]
Holmgren, B. 1971. Climate and energy exchange on a sub-polar ice cap in summer. Arctic Institute of North America Devon Island Expedition, 1961-1963. Part E. Radiation climate. Uppsala Universitet. Meteorologiska Institutionen. Meddelanden Nr. 111.

Jacobs, J.D., and others. 1973. Glaciological and meteorological studies on the Boas Glacier, Baffin Island, for two contrasting seasons (1969-70 and 1970-71), by J.D. Jacobs, J.T. Andrews, R.G. Barry, R.S. Bradley, R. Weaver, and L.D. Williams. (In [International Hydrological Decade.] The role of snow and ice in hydrology. Proceedings of the Banff symposia, September 1972. A contribution to the International Hydrological Decade. Paris, UNESCO; Geneva, WMO; Budapest, IAHS, Vol. 1, p. 371-82. (Publication No. 107 de l'Association Internationale d'Hydrologie Scientifique.))

Kuhn, M., and others. 1975. The radiation balance of Plateau Station, Antarctica, 1966, 1967, by M. Kuhn, L.S. Kundla, and A. Stroschein. (In Meteorological studies of Plateau Station, Antarctica. Innsbruck, Universität Innsbruck. Institut für Meteorologie und Geophysik, p. 41-73.)

Liljequist, G.H. 1956. Energy exchange of an Antarctic snow-field; a short-wave radiation. Norwegian-BritishSwedish Antarctic Expedition, 1949-1952. Scientific Results, Vol. 2, Pt. 1A.

Marshunova, M.S., and Chernigovskiy, N.T. 1968. Kharakteristica radiatsionnykh usloviy $\mathrm{v}$ Arktike $\mathrm{v}$ period MGSS [Characteristics of radiation conditions in the Arctic during the IQSY]. Trudy Arkticheskogo $i$ Antarkticheskogo Nauchno-Issledovatel'skogo Instituta, Tom 274 , p. 22-35. [English translation: Jerusalem, Israel Program for Scientific Translation, 1971, p. 20-34.]

Müller, H. 1984. Zum Strahlungshaushalt im Alpenraum. Eidgenössische Technische Hochschule Zürich. Versuchsanstalt für Wasserbau, Hydrologie und Glaziologie. Mitteilungen, Nr. 71.

Robinson, D.A., and others. 1985. Arctic cloud cover during the summers of 1977-1979, by D.A. Robinson, G.J. Kukla, and M.C. Serreze. New York, Columbia University. Lamont-Doherty Geological Observatory. (Technical Report L-DGO-85-5.)

Robinson, D.A., and others. 1986. Snow melt and surface albedo in the Arctic Basin, by D.A. Robinson, G. Scharfen, M.C. Serreze, G.J. Kukla, and R.G. Barry. Geophysical Research Letters, Vol. 13, No. 9, p. 945-48.

Scharfen, G., and others. 1987. Large-scale patterns of snowmelt on Arctic sea ice from meteorological satellite imagery, by G. Scharfen, R.G. Barry, D.A. Robinson, G.J. Kukla, and M.C. Serreze. Annals of Glaciology, Vol. 9, p. $200-05$.

Schneider, S.H., and Dickinson, R.E. 1976. Parameterization of fractional cloud amounts in climatic models: the importance of modeling multiple reflections. Journal of Applied Meteorology, Vol. 15, p. 1050-56.

Vowinckel, E., and Orvig, S. 1962. Relation between solar radiation income and cloud type in the Arctic. Journal of Applied Meteorology, Vol. 1, No. 4, p. 552-59.

Wendler, G., and others. 1981. Multiple reflection effects on irradiance in the presence of Arctic stratus clouds, by G. Wendler, F.D. Eaton, and T. Ohtake. Journal of Geophysical Research, Vol. 86, No. C3, p. 2049-57.

Wilson, C. 1972. Net radiation during cloudy, damp conditions in the snow-free season at Poste-de-la-Baleine (Great Whale), Québec. Cahiers de Géographie de Québec, Vol. 16, No. 39, p. 411-18.

Wiscombe, W.J., and Warren, S.G. 1980. A model for the spectral albedo of snow, I: Pure snow. Journal of the Atmospheric Sciences, Vol. 37, No. 12, p. 2712-33. 